\title{
Vanadium Alloy Steel DIN 30MnVS6 Applied in Cold Forging Process
}

\author{
Bruno Inácio Da MAIA, ${ }^{*}$ André Hideto FUTAMI and Marco Aurélio De OLIVEIRA \\ Research and Technology Dept., University Center SOSIESC - UNISOCIESC, CEP 89206-001 Joinville, Santa Catarina, Brazil. \\ (Received on May 17, 2018; accepted on August 2, 2018; J-STAGE Advance published date: September \\ $28,2018)$
}

\begin{abstract}
Vanadium alloy steels are still little known and debated when applied to the cold forming process, it is not clear what the performance of their mechanical performance is compared to traditional steels that the market already uses.

The possibility of reducing costs and generating competitiveness, are the basis for studies that generate new opportunities for industries. In this article, the possibility of withdrawing the heat treatment process, directed the performance of the tests presented here.

This paper deals with the performance comparison of DIN 30MnVS6 steel compared to ISO 898-1, which deals with mechanical performance for bolts. The tests were correlated with the bolts of resistance class 8.8, which currently have heat treatment. It is possible to evaluate the positive performance of the vanadium-alloyed steel DIN 30MnVS6, despite the occasional performance limitations in some attributes addressed in ISO 898-1.
\end{abstract}

KEY WORDS: DIN 30MnVS6; cold forming; vanadium micro-alloyed carbon; fasteners.

\section{Introduction}

Steels with the addition of vanadium is still little used in cold forming. In the automotive industry, the use of micro-alloyed steel DIN 30MnVS6 to form hot forged parts enables a reduction in the processing time of the components. ${ }^{1,4,6,22)}$ This is because the hardness and strength of forged parts using micro-alloyed steels are obtained through the mechanisms of the grain refinement and precipitation hardening caused by the alloying elements during the mechanical conformation, thus enabling the elimination of the subsequent heat treatment process. ${ }^{1-3,7)}$

In cold forming this process is still little studied, the possibility of forming products without the use of heat treatment would reduce manufacturing costs, decrease production times and generate greater competitiveness in the market. $^{7,9,10)}$

Some researchers mentioned three areas of use of Vanadium alloy steel for the manufacture of bolts: for fasteners without heat treatment, for the reduction of alloyed elements of heat-treated bolts and for fasteners of high resistance. For the untreated bolts developed a cold forging machine wire that exhibited resistance levels of $700 \mathrm{MPa}$ without spheroidization, quenching or tempering. The steel composition was a low carbon bonded to the Mn with minor additions of $\mathrm{Nb}, \mathrm{V}$ and Ti obtaining a perlite ferrite structure under controlled rolling and cooling conditions. ${ }^{8,18,21)}$

\footnotetext{
* Corresponding author: E-mail: inaciodamaia@gmail.com DOI: https://doi.org/10.2355/isijinternational.ISIJINT-2018-342
}

In view of this lack of knowledge, this study proposes to assist in the bibliographical and practical complement with tests of DIN 30MnVS6 material conformed in the cold without the application of thermal treatment..$^{8,10,12,18,20,23)}$ For comparison and results, DIN 30MnVS6 material will be used in the manufacture of 8.8 bolts (requiring heat treatment), and compared to SAE 10B30 (boron bonded steel with heat treatment). ${ }^{6,26,28)}$

\section{Experimental Procedure}

The bolts were shaped into an organization that manufactures these types of product and has the appropriate equipment for its manufacture, first step was cold formers machines, second was thread lamination and third was heat treatment only for bolts made by steel SAE 10B30. The steels used to manufacture the samples were DIN 30MnVS6 and SAE 10B30, as can be evaluated, Table 1 contains the chemical composition of these materials. The reading and control of the chemical composition of the steel was done through the spectrometer Shimadzu PDA 7000.

Currently, the bolts is produced with SAE 10B30 steel and meet the requirements for heat treatment and performance 8.8 , according to ISO 898-1.

The production batches were of M16 diameter, the SAE 10B30 steel bolts went through the heat treatment process, while the bolts made of DIN 30MnVS6 steel did not pass. Both used the same forming machine and the same set of tooling, the only change in the process was the addition of the heat treatment for SAE 10B30 steel products. 
In the Fig. 1, is possible to evaluate the microstructure of DIN 30MnVS6, expansion of 500X. The micro-alloyed carbon steel 30MnVS6, does not present a martensitic structure but a ferritic-pearlite structure. Carbide and vanadium nitride have high solubility and are almost completely dissolved in austenite and therefore have little influence on grain size control.

In the Fig. 2, is possible to evaluate the microstructure of SAE 10B30 without heat treatment, expansion of 500X. The micro-alloyed carbon steel SAE 10B30, does Perlite matrix with grain boundary ferrite network.

The tests used to evaluate the performance of the products were as specified in ISO 898-1, were composed of; tests minimum ultimate tensile loads, proof load, Vickers hardness, Charpy and Strictness. The tests were carried out in the internal laboratory of the study organization, the same equipment was used and the tests performed by the same operator. The 25 pieces sampling was used for each measurement type, after which the dispersion and the average of each type of material were evaluated. For the Charpy test was used 5 pieces sampling.

The presence of Manganese (Mn) in high concentrations is fundamental to obtain solid solution hardening and

Table 1. Chemical Composition (wt $\%$ ) of the DIN 30MnVS6 and SAE 10B30.

\begin{tabular}{ccc}
\hline Steel & DIN 30MnVS6 & SAE 10B30 \\
\hline $\mathrm{C}$ & 0,31 & 0,32 \\
$\mathrm{Si}$ & 0,62 & 0,28 \\
$\mathrm{Mn}$ & 1,35 & 0,9 \\
$\mathrm{P}$ & 0,019 & 0,01 \\
$\mathrm{~S}$ & 0,024 & 0,02 \\
$\mathrm{Cr}$ & 0,23 & 0,37 \\
$\mathrm{Mo}$ & 0,06 & 0,05 \\
$\mathrm{~V}$ & 0,12 & - \\
$\mathrm{N}$ & 0,012 & \\
$\mathrm{~B}$ & - & 0,0025 \\
\hline
\end{tabular}

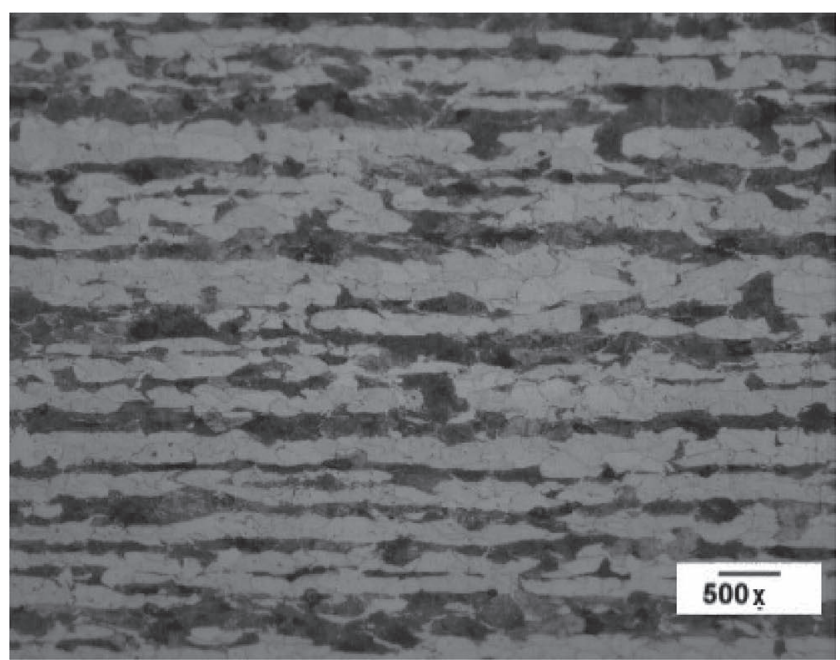

Fig. 1. Photomicrography of 30MnVS6 micro-alloyed carbon steel (expansion 500X). promote a combination of mechanical strength, hardness and ductility. As expected, Manganese is in concentrations higher than micro-alloyed elements and within the range specified by DIN EN 10267.

After the manufacture numerical simulation, the two types of samples were conformed, as can be observed according the Fig. 3.

The stamping force values obtained with the simulation necessary to forge the samples with different materials can be see according the Table 2 . It is possible to visualize the differences in the force of conformation and the percentage of increase of force of the DIN 30MnVS6steel to that of the SAE10B30.

\section{Results}

The results obtained can be evaluated in Table 3 . Accord-

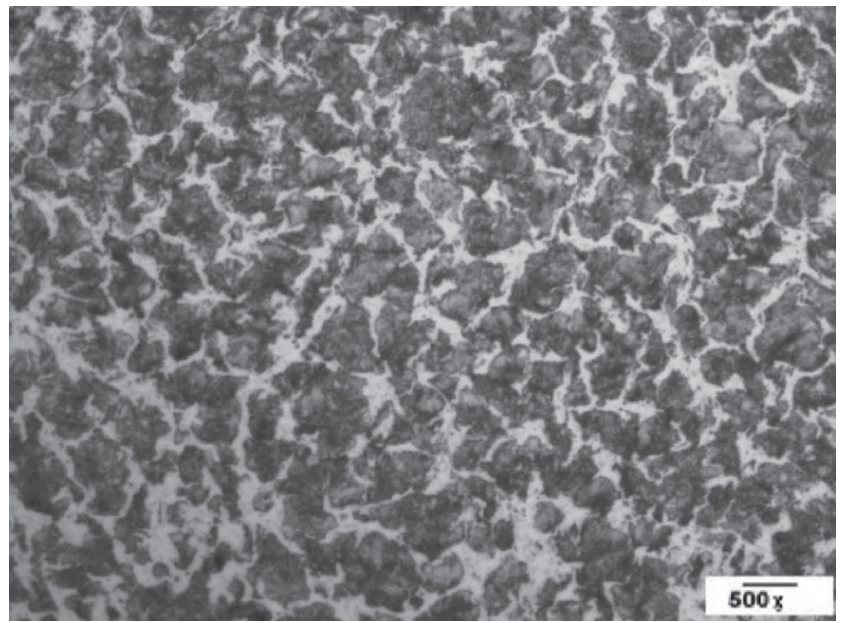

Fig. 2. Photomicrography of SAE $10 \mathrm{~B} 30$ without heat treatment (expansion 500X).

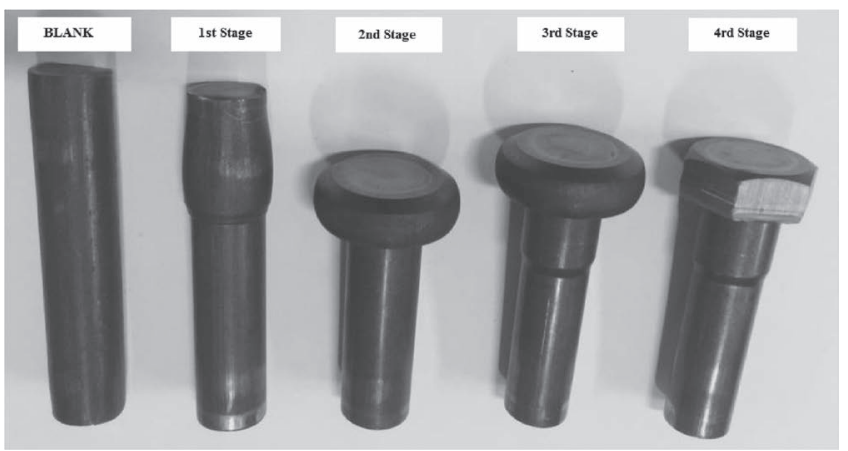

Fig. 3. Bolts samples steel DIN30MnVS6.

Table 2. Forging force.

\begin{tabular}{ccccc}
\hline & \multicolumn{4}{c}{ Forging Force $(\mathrm{kN})$} \\
\hline Material & $\begin{array}{c}\text { 1st } \\
\text { Stage }\end{array}$ & $\begin{array}{c}\text { 2nd } \\
\text { Stage }\end{array}$ & $\begin{array}{c}\text { 3rd } \\
\text { Stage }\end{array}$ & $\begin{array}{c}\text { 4th } \\
\text { Stage }\end{array}$ \\
\hline DIN 30MnVS6 & 73 & 196 & 17 & 10 \\
SAE10B30 & 34 & 93 & 10 & 6 \\
$\begin{array}{c}\text { (\%) (DIN 30MnVS6/SAE } \\
\text { SAE10B30) - }\end{array}$ & $115 \%$ & $111 \%$ & $70 \%$ & $67 \%$ \\
\hline
\end{tabular}


ing to the comparison between the specification of the standard and the average of the 25 results achieved for each steel type, one can make the product performance and steel change validity considerations.

The results expressed the averages of the values obtained in the measurement of the 25 samples of each type of steel, only the Charpy test was 5 samples.

By comparing the results of the test force for the manufacture of the bolts, approximately twice the force is required if using the DIN 30MnVS6 micro-alloyed carbon steel. Was considered the same product for manufacturing performance comparison, same reduction diameters, same extruded lengths and other dimensions, more details like the Fig. 4.

With this, it can be concluded that the wear of labor tends to be higher than that of the bonded carbon steel SAE 10B30. It is important that the useful life also depend on other factors that are not oriented to the present, such as the type of lubrication used during the editing, the material used in the manufacturing of the dies (quality and type of tool steel), the thermal treatment of its operations and its surface condition, among others.
It was not possible to evaluate tool wear because the batch was experimental. For a more in-depth analysis of the performance of the tools it is necessary to make lots of scale.

When DIN 30MnVS6 steel was used, it was possible to evaluate the beginning of wear and tear on the punches (hammers) of the first and second forming, characterized by tool marks. The forming forces of the first formations are larger due to the higher settling rate in relation to the other formations, the tool needs to make greater effort in these steps to drain and conform the steel.

The third and fourth formation matrices responsible for extrusion and chamfering of the product did not show any failure or signaling of possible breaks or wear. The material DIN 30MnVS6 presents positivity for extrusion when compared to the SAE 10B30, including this is evident in the forces of formation, being in these operations the most similar between both materials.

Severe deformations can cause problems like cracks in the material or even the poor filling of material in the head of the bolts. The influence of the sulfur is directly linked to the formation of inclusions can cause a great anisotropy leading to the reduction of the toughness in the direction

Table 3. Tests results for DIN $30 \mathrm{MnVS} 6$ and SAE 10B30.

\begin{tabular}{cccccc}
\hline $\begin{array}{c}\text { Test Specification M16 } \\
\text { Class 8.8 per ISO 898-1 }\end{array}$ & $\begin{array}{c}\text { Specification ISO } \\
989-1\end{array}$ & $\begin{array}{c}\text { Results of } \\
\text { SAE 10B30 }\end{array}$ & $\begin{array}{c}\text { Standard Deviation } \\
\text { SAE 10B30 }\end{array}$ & $\begin{array}{c}\text { Results of DIN } \\
\text { 30MnVS6 }\end{array}$ & $\begin{array}{c}\text { Standard Deviation DIN } \\
\text { 30MnVS6 }\end{array}$ \\
\hline $\begin{array}{c}\text { Minimum Ultimate } \\
\text { Tensile Loads (N) }\end{array}$ & 125.000 & 142.200 & 7.280 & 147.800 & 9.355 \\
Proof Load (N) & 91.000 & 91.000 & - & 91.000 & - \\
Vickers Hardness, (HV) & $250-320$ & 309 & 10.81 & 280 & 8.77 \\
Charpy (J) "V" -20 ${ }^{\circ} \mathrm{C}$ & $>27$ & 16 & 2.4 & 18 & 1.8 \\
Strictness (\%) & $>52$ & 54.8 & 1.45 & 34.2 & 3.68 \\
\hline
\end{tabular}
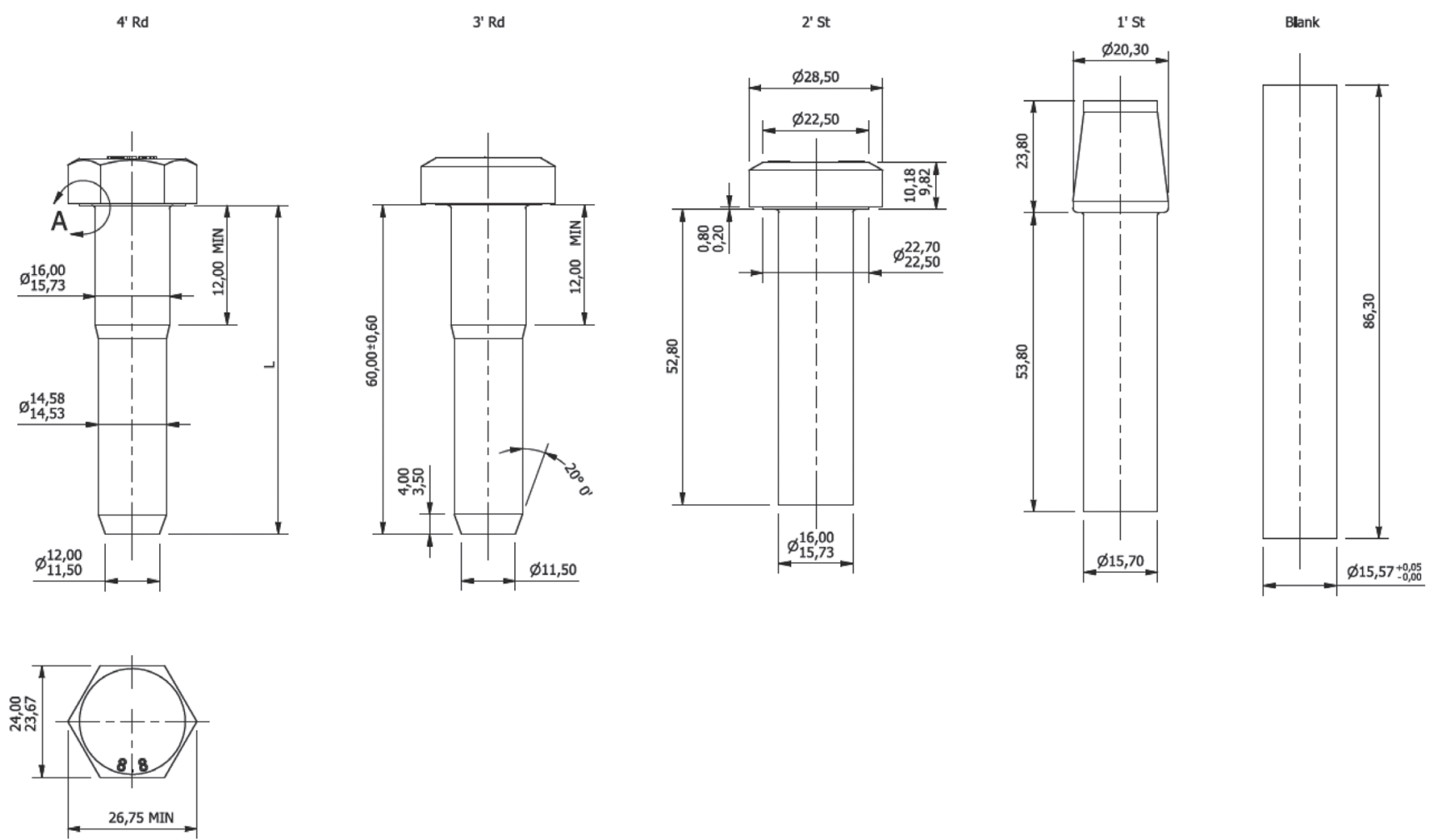

Fig. 4. Forging and dimensions product sequence. 
perpendicular to the lamination and fiber. Treatments to control the shape of inclusions can increase the toughness of mechanically shaped materials. This fact can be related to the presence of sulfur, found in the chemical composition of the micro-alloyed carbon steel, usually extremely damaging to steel. It detracts from ductility, especially transverse folding, and reduces weldability. It weakens the steels during work, since the same influence in the decrease of the formability of the material.

In the Fig. 5, is possible to evaluate the microstructure of SAE10B30 steel after austenitization. It is possible to prove the transformation of the material and the martensitic structure, matrix martensitic revenge level of transformation $100 \%$, which ensures that the products conforming to this steel meet the requirements of ISO 898-1.

\section{Discussion}

It was possible to evaluate in the metallographic analysis that micro-alloyed steel DIN 30MnVS6 does not present a martensitic microstructure, but rather, ferritic-pearlite. ${ }^{3,8,12,15)}$ The results presented in Table 4, meet almost fully resistance class 8.8 according to ISO 898-1, except for the result of the strictness. The charpy assay is generally required for products with a strength class of more than 8.8 , as ISO 898-1 states that this test may be required for smaller resistance classes, so this study has addressed this situation. The result was negative, since it did not meet the $27 \mathrm{~J}$ requested in the standard.

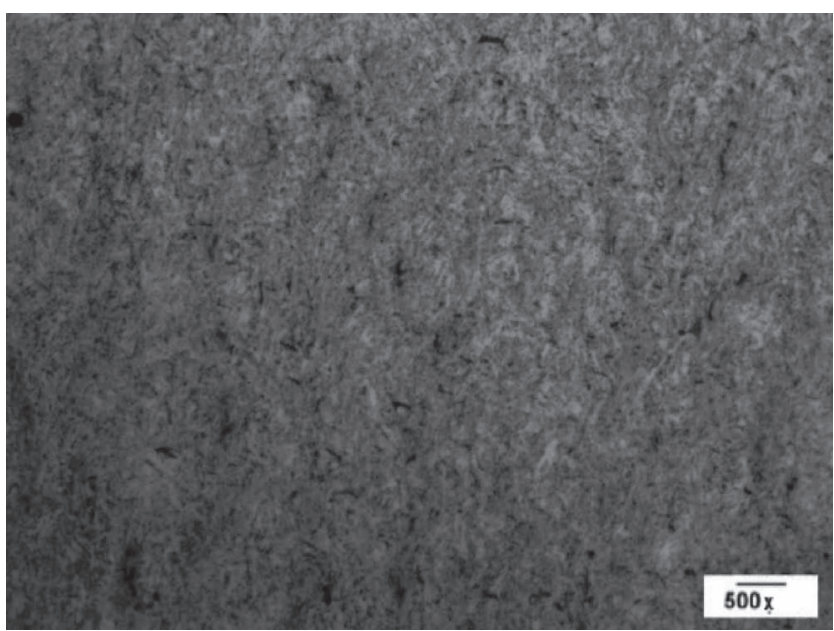

Fig. 5. Photomicrography of SAE $10 \mathrm{~B} 30$ with heat treatment (expansion 500X)
In addition, the conformation of this material presented difficulties in its use, since the simulations showed the need for a greater stamping force for the conformation of the samples. This data may indicate a greater wear of tooling and a limitation as to the severity of deformations.

It's observed as positive results the full attendance to the tests minimum ultimate tensile loads, proof load and Vickers hardness. Carbonation as well as decarburizing are characteristic properties of thermally treated parts after forming. Therefore, bolts made of DIN 30MnVS6 micro-rolled steel do not suffer from these phenomena.

Due to the results obtained with the physical and mechanical tests carried out in this work, it can be inferred that the micro-alloyed carbon steel DIN 30MnVS6 is characteristic because it is a material of lower ductility and of less tenacity. A consequence of this, the physical and mechanical properties established by ISO 898-1 were compromised on Strictness test.

Some advantages can be listed on the possibility of changing the raw material, like;

$\Rightarrow$ Manufacturing lead time gains

$\Rightarrow$ Cleaner/environmentally friendly production

$\Rightarrow$ Elimination of heat treatment process

$\Rightarrow$ No risk of decarburization

$\Rightarrow$ No risk of delta ferrite

$\Rightarrow$ No need to apply the dehydrogenation process when applied superficial surface treatments (zinc, galvanizing, etc.)

$\Rightarrow$ Development of innovative products

$\Rightarrow$ Possibility of changes of raw material

The vanadium alloy steels, meets the mechanical characteristics by the only cold forming process, which extinguishes the need for the heat treatment process. The extinction of the heat treatment process generates gains, as previously exposed, in such a way; the organizations have generated competitiveness for their products and technological gains in the manufacturing process.

The industries have the possibility of adopting in the specification of their engineering projects raw materials such as the one addressed in this study; they can be alternative solutions to the products that need specific characteristics of mechanical performance.

\section{Conclusions}

This article presented in a succinct and direct way the possibility of changing the specifications of raw material to obtain the same product, reducing the process of thermal

Table 4. Results of testing SAE 10B30 vs DIN 30MnVS6.

\begin{tabular}{|c|c|c|c|c|c|c|c|}
\hline \multirow{2}{*}{$\begin{array}{l}\text { Test Specification M16 } \\
\text { Class } 8.8 \text { per ISO } 898-1\end{array}$} & \multirow{2}{*}{$\begin{array}{l}\text { Specification } \\
\text { ISO 989-1 }\end{array}$} & \multicolumn{2}{|c|}{ Results of SAE $10 \mathrm{~B} 30$} & \multirow{2}{*}{$\begin{array}{c}\text { Status } \\
\text { SAE10B30 }\end{array}$} & \multicolumn{2}{|c|}{ Results of DIN 30MnVS6 } & \multirow{2}{*}{$\begin{array}{c}\text { Status DIN } \\
\text { 30MnVS6 }\end{array}$} \\
\hline & & Min. & Max. & & Min. & Max. & \\
\hline $\begin{array}{l}\text { Minimum Ultimate } \\
\text { Tensile Loads (N) }\end{array}$ & 125.000 & 134.920 & 149.480 & $\mathrm{OK} !$ & 138.445 & 157.155 & $\mathrm{OK} !$ \\
\hline Proof Load (N) & 91.000 & 91.000 & - & $\mathrm{OK} !$ & 91.000 & - & $\mathrm{OK} !$ \\
\hline Vickers Hardness, (HV) & $250-320$ & 298.19 & 319.81 & OK! & 271.23 & 288.77 & $\mathrm{OK} !$ \\
\hline Charpy (J) "V" $-20^{\circ} \mathrm{C}$ & $>27$ & 13.60 & 18.40 & $\mathrm{X}$ & 16.20 & 19.80 & $\mathrm{X}$ \\
\hline Strictness (\%) & $>52$ & 53.35 & 56.25 & OK! & 30.52 & 37.88 & $\mathrm{X}$ \\
\hline
\end{tabular}


treatment.

For the use of micro-alloyed steel, DIN 30MnVS6 to made possible in the cold forming of bolts. This study addressed the possibility of adaptation of the raw material change to products that need to achieve specific mechanical performance characteristics, with the advantage of not having to go through the heat treatment process. The products meet their characteristics of mechanical resistance by the process of cold forming. Thus, complementary studies with other types of products are necessary to complement and explore this research.

This study complements the current literature in the field of knowledge of cold-formed steels involving vanadium alloys.

\section{REFERENCES}

1) A. Clair, M. Foucault, O. Calonne, Y. Lacroute, L. Markey, M. Salazar, V. Vignal and E. Finot: Acta Mater., 59 (2011), 3116.

2) A. Kamp, S. Celotto and D. N. Hanlon: Mater. Sci. Eng. A, 538 (2012), 35.

3) A. Hamada and J. Kömi: Mater. Sci. Eng. A, 718 (2018), 301.

4) A. Rajini, M. Nookaraju, K. Selvaraj, I. Reddy and V. Narayanan: Mater. Res., 16 (2013), 181.

5) B. Pan, K. Qian, H. Xie and A. Asundi: Meas. Sci. Technol., 20 (2009), 062001.

6) B. Dutta and C. M. Sellars: Mater. Sci. Technol., 3 (1987), 197.

7) B. Hutchinson, D. Martin, O. Karlsson, F. Lindberg, H. Thoors, R. K. W. Marceau and A. S. Taylor: Mater. Sci. Technol., 33 (2017), 497.

8) C. J. McMahon and M. Cohen: Acta Metall., 13 (1965), 591.

9) C. H. Lee, J. Y. Park, J. Chung, D. B. Park, J. Y. Jang, S. Huh and T. H. Lee: Mater. Sci. Eng. A, 651 (2016), 192.

10) D. Grygier, M. Rutkowska-Gorczyca, R. Jasiński and W. Dudziński: Arch. Metall. Mater., 61 (2016), 971.

11) DIN EN 10267: 1998, Ferritic-pearlitic steels for precipitation hardening from hot-working temperatures.

12) E. Jimenez-Melero, N. H. van Dijk, L. Zhao, J. Sietsma, J. P. Wright and S. van der Zwaag: Mater. Sci. Eng. A, 528 (2011), 6407.
13) H. Ghadbeigi, C. Pinna and S. Celotto: Exp. Mech., 52 (2012), 1483.

14) H. Gondo, T. Yoshimura, M. Araki and N. Eguchi: Nippon Steel Tech. Rep., 303 (1980), 75.

15) H. Gwon, J. K. Kim, S. Shin, L. Cho and B. C. de Cooman: Mater. Sci. Eng. A, 696 (2017), 416.

16) ISO 898-1: 2013, Mechanical properties of fasteners made of carbon steel and alloy steel - Part 1: Bolts, screws and studs with specified property classes - Coarse thread and fine pitch thread.

17) K. Nakashima, Y. Fujimura, H. Matsubayashi, T. Tsuchiyama and S. Takaki: Tetsu-to-Hagané, 93 (2007), 459.

18) M. Mukherjee, O. N. Mohannty, S. Hashimoto, T. Hojo and K. Sugimoto: ISIJ Int., 46 (2006), 316.

19) M. Takahashi: Nippon Steel Tech. Rep., 88 (2003), 2.

20) N. Kamikawa, K. Sato, G. Miyamoto, M. Murayama, N. Sekido, K. Tsuzaki and T. Furuhara: Acta Mater., 83 (2015), 383.

21) O. I. Nokhrina, I. D. Rozhikhina, V. I. Dmitrienko, M. A. Golodova and Y. A. Osipova: Steel Transl., 45 (2015), 543.

22) R. H. Larn and J. R. Yang: Mater. Sci. Eng. A, 264 (1999), 139.

$23)$ R. Lagneborg, T. Siwecki, S. Zajac and B. Hutchinson: Scand. J. Metall., 28 (1999), 186.

24) S. Herbst, M. Schledorn, H. J. Maier, A. Milenin and F. Nürnberger: J. Mater. Eng. Perform., 25 (2016), 1453.

25) S. T. Mandziej, S. Waengler, J. Noack and R. Kawalla: Mater. Sci. Forum, 638 (2010), 2652.

26) T. Moritani, N. Miyajima, T. Furuhara and T. Maki: Scr. Mater., 47 (2002), 193.

27) T. Siwecki, J. Eliasson, R. Lagneborg and B. Hutchinson: ISIJ Int., 50 (2010), 760.

28) T. Sourmail, C. Garcia-Mateo, F. G. Caballero, S. Cazottes, T. Epicier, F. Danoix and D. Milbourn: Metall. Mater. Trans. A., 48 (2017), 3985.

29) T. Taylor and P. Evans: Mater. Des., 86 (2015), 714

30) W. Hui, S. Chen, Y. Zhang, C. Shao and H. Dong: Mater. Des., 66 (2015), 227.

31) Y. Sakuma, D. K. Matlock and G. Krauss: Metall. Trans. A, 23 (1992), 1221.

32) Y. Li, D. N. Crowther, M. J. W. Green, P. S. Mitchell and T. N. Baker: Thermomechanical Processing of Steels, The Institute of Materials, London, (2000), 69.

33) Y. Li, D. N. Crowther, M. J. W. Green, P. S. Mitchell and T. N. Baker: ISIJ Int., 41 (2001), 46.

34) Y. Li, D.N. Crowther, P. S. Mitchell and T. N. Baker: ISIJ Int., 42 (2002), 636. 